Article

\title{
In Vitro Tumor Cell Growth Inhibition Induced by Lophocereus marginatus (DC.) S. Arias and Terrazas Endophytic Fungi Extracts
}

\author{
Jesica M. Ramírez-Villalobos ${ }^{1}$ (D) César I. Romo-Sáenz ${ }^{1, *(\mathbb{D})}$, Karla S. Morán-Santibañez ${ }^{1} \mathbb{D}$, \\ Patricia Tamez-Guerra ${ }^{1}$, Ramiro Quintanilla-Licea ${ }^{2}$, Alonso A. Orozco-Flores ${ }^{1}$, Ricardo Romero-Arguelles ${ }^{1}$, \\ Reyes Tamez-Guerra ${ }^{1}$, Cristina Rodríguez-Padilla ${ }^{1}$ (D) and Ricardo Gomez-Flores ${ }^{1, *(D)}$
}

1 Departamento de Microbiología e Inmunología, Facultad de Ciencias Biológicas, Universidad Autónoma de Nuevo León, San Nicolás de los Garza 66455, Mexico; jesicamrv_901@hotmail.com (J.M.R.-V.); karlita_moran@hotmail.com (K.S.M.-S.); patamez@hotmail.com (P.T.-G.); lacxelo@gmail.com (A.A.O.-F.); ricardoromeroarguelles@gmail.com (R.R.-A.); reyes.tamezgr@uanl.edu.mx (R.T.-G.); crrodrig07@gmail.com (C.R.-P.)

2 Departamento de Química, Universidad Autónoma de Nuevo León, San Nicolás de los Garza 66455, Mexico; rquintanilla.uanl@gmail.com

check for

updates

Citation: Ramírez-Villalobos, J.M.; Romo-Sáenz, C.I.; Morán-Santibañez, K.S.; Tamez-Guerra, P.; QuintanillaLicea, R.; Orozco-Flores, A.A.; Romero-Arguelles, R.; Tamez-Guerra, R.; Rodríguez-Padilla, C.; GomezFlores, R. In Vitro Tumor Cell Growth Inhibition Induced by Lophocereus marginatus (DC.) S. Arias and Terrazas Endophytic Fungi Extracts Int. J. Environ. Res. Public Health 2021, 18, 9917. https://doi.org/10.3390/ ijerph18189917

Academic Editors: Angela F. Cunha and Paul B. Tchounwou

Received: 18 July 2021

Accepted: 19 September 2021

Published: 21 September 2021

Publisher's Note: MDPI stays neutral with regard to jurisdictional claims in published maps and institutional affiliations.

Copyright: (C) 2021 by the authors Licensee MDPI, Basel, Switzerland This article is an open access article distributed under the terms and conditions of the Creative Commons Attribution (CC BY) license (https:// creativecommons.org/licenses/by/ $4.0 /)$
* Correspondence: cesar_ivan_romo@hotmail.com (C.I.R.-S.); rgomez60@hotmail.com (R.G.-F.)

Abstract: Endophytic fungi have become potential sources of antitumor agents, particularly against antineoplastic-resistant cancer cells, with marginal or nil adverse effects for the oncological patient. Endophytic fungi were isolated from stems of the Lophocereus marginatus cactus, commonly found in Mexico. Methanol extracts were then obtained from fungus liquid cultures and their effects on tumor cell growth against murine lymphoma (L5178Y-R), human colorectal adenocarcinoma (HT-29), and human breast cancer (MCF-7) cells were evaluated at concentrations ranging from $31 \mu \mathrm{g} / \mathrm{mL}$ to $250 \mu \mathrm{g} / \mathrm{mL}$ via the colorimetric 3- [4,5-dimethylthiazol-2-yl]-2,5-diphenyltetrazoliumbromide reduction assay, using monkey kidney epithelial (MA-104) and human peripheral mononuclear (PBMC) cells as controls. Furthermore, we obtained the $\mathrm{IC}_{50}$ and the selectivity index (SI) was calculated from the $\mathrm{IC}_{50}$ ratio of normal and tumor cells. In addition, molecular identification of fungi showing cytotoxic activity was determined, using internal transcribed spacer molecular markers. PME-H001, PME-H002, PME-H005, PME-H007, and PME-H008 filamentous fungus strain extracts showed significant $(p<0.05)$ tumor cell growth inhibition. In particular, they significantly $(p<0.05)$ inhibited L5178Y-R cell growth, whereas the least susceptible cell line was HT-29. The endophytic strain PME-H008 of Cladosporium sp. caused the highest growth inhibition percentage against L5178Y-R and HT-29 cells with 96.6\% $(p<0.01)$ and $42.5 \%(p<0.05)$ respectively, and the highest SIs against L5178Y-R cells with 2.4 and 2.9 for MA-104 and PBMCs, respectively, whereas the PME-H005 extract showed SIs of 2.77 and 1.5 against MCF-7 and L5178Y-R cells, respectively, as compared with PBMCs. In addition, the endophytic strain PME-H007 of Metarhizium anisopliae caused the highest percentage of growth inhibition $(p<0.01)$ against MCF-7 cells with 55.8\% at $250 \mu \mathrm{g} / \mathrm{mL}$. We demonstrated in vitro antitumor effects of $L$. marginatus endophytic fungi. Further research will involve the isolation and in vivo testing of bioactive compounds.

Keywords: antitumor; endophytic fungi; Cactaceae; Lophocereus marginatus; natural sources; environmentally friendly; Mexican plants; medicinal plants

\section{Introduction}

In 2020, around 9.9 million deaths by cancer were reported in the GLOBOCAN database [1], despite the existence of a variety of therapeutic approaches [2]. In particular, chemotherapy represents a common treatment, but severe side effects to the patients are usually observed. In addition, the emergence of antineoplastic-resistant cancer cells has 
become one of the main causes of treatment failure [3]. Therefore, it is essential to search for new drugs with marginal or no adverse effects for the oncological patient [4], and to which resistance has not been developed.

Endophytic fungi have gained relevance in biotechnology as potential sources of new compounds with antitumor activity. Their rapid growth, culture conditions, high cell density, easy genetic manipulation, and the possibility of scaling the production of compounds at an industrial level make them candidates for obtaining more efficacious anticancer drugs [5].

It has been proposed that the isolation of endophytic fungi, involving the selection of plants with ethnobotanical use, as well as those that have developed strategies for survival or growth under extreme environments [6], may lead to the discovery of endophytes that produce novel bioactive compounds. In this regard, arid-zone plants such as cacti establish symbiotic relationships with different microorganisms, from which enzymes [7], antimicrobials [8], and anticancer compounds such as bikaverine [9] and triterpenes of the 24-homo-30-nor-cycloartane class [10] have been isolated. However, the biotechnological potential of fungi isolated from dessert plants has not been fully investigated [11].

Lophocereus marginatus, also known as Pachycereus marginatus, is a species of cactus endemic to Mexico and belonging to the Cactaceae family. It is popularly known as chilayo, organ cactus, or malinche [12]. In traditional medicine, it has been used for the treatment of gastrointestinal diseases [13] and diabetes [14]. Recent studies have demonstrated the antimicrobial [15] and anticancer activity of L. marginatus extracts in in vitro [16,17] and in vivo models [18]. However, the anticancer potential of $L$. marginatus endophytic fungi have not yet been reported. The aim of the present study was to isolate and evaluate the antitumor potential of L. mariginatus endophytic fungi against murine and human cancer cell lines.

\section{Materials and Methods}

\subsection{Plant Material}

L. marginatus stems were collected in General Escobedo, Nuevo León, México $\left(25^{\circ} 47^{\prime} 15.7^{\prime \prime}\right.$ $\mathrm{N} 100^{\circ} 17^{\prime} 32.6^{\prime \prime} \mathrm{W}$ ) in February 2020. This cactus was identified by M.Sci. María del Consuelo González de la Rosa, Chief of the Herbarium of Facultad de Ciencias Biológicas at Universidad Autónoma de Nuevo León, México, with voucher specimen number 025588.

\subsection{Isolation and Morphological Characterization of L. marginatus Endophytic Fungi}

Stems were rinsed with tap water to eliminate dust and other contaminating material, and subjected to a disinfection protocol to remove epiphytes, which consisted of washing with $70 \%$ ethanol for $1 \mathrm{~min}, 2.5 \%$ sodium hypochlorite for $3 \mathrm{~min}, 70 \%$ ethanol for $30 \mathrm{~s}$, and two rinses with sterile distilled water and one with PBS [19]. For the isolation of endophytic fungi, the previously disinfected plant tissue was cut into small pieces $\left(\sim 0.5 \mathrm{~cm}^{2}\right)$. One part was placed on the surface of Petri dishes containing potato dextrose agar (PDA; Difco, Detroit, MI, USA), Sabouraud dextrose agar (SA; Difco), and water agar containing $60 \mathrm{mg} / \mathrm{L}$ penicillin and $100 \mathrm{mg} / \mathrm{L}$ streptomycin (Life Technologies, Grand Island, NY, USA) to inhibit microbial growth, and the other part was ground in PBS in a sterile mortar. Next, $100 \mu \mathrm{L}$ of the sample was inoculated into the aforementioned culture medium by plate dispersion and the last wash with PBS was used as a negative growth control. Plates were then incubated at $20^{\circ} \mathrm{C}$ for four weeks. Morphological characterization was determined from monosporic cultures of the isolates in PDA, with radial growth, shape, size, color, edge, and type of mycelium recorded. Isolated fungi were registered with isolate codes PME-H00\#.

\subsection{Fermentation and Production of Methanol Extracts}

For the extraction of secondary metabolites, $1 \mathrm{~cm}^{2}$ fresh culture fragments were individually inoculated into $250 \mathrm{~mL}$ flasks with $125 \mathrm{~mL}$ of potato and dextrose broth (PDB; Difco) and incubated for $30 \mathrm{~d}$ at $20^{\circ} \mathrm{C}$ and $150 \mathrm{rpm}$ (ET-4200, Tecnal Incubator, São Paulo, 
Brazil). After incubation, mycelium was separated by filtration and dried at $60{ }^{\circ} \mathrm{C}$, after which it was subjected to an extraction via maceration with methanol. Solvent was then removed with a rotary evaporator (Buchi R-3000; Brinkman Instruments, Inc., Westbury, NY, USA). Extracts were dissolved in dimethyl sulfoxide (DMSO; Sigma-Aldrich, St. Louis, $\mathrm{MO}, \mathrm{USA}$ ) at a final concentration of $25 \mathrm{mg} / \mathrm{mL}$ and kept at $4{ }^{\circ} \mathrm{C}$ until use.

\subsection{Cell Lines and Culture Conditions}

The cell lines used in this study were the murine lymphoma line L5178Y-R (ATCC CRL-1722), the human colorectal adenocarcinoma line HT-29 (ATCC HTB-38), the human breast cancer line MCF-7 (ATCC HTB-2), and the monkey kidney epithelial cell line MA-104 (ATCC CRL-2378.1). Peripheral blood mononuclear cells (PBMCs) were obtained from $20 \mathrm{~mL}$ to $30 \mathrm{~mL}$ (three experiments were performed) samples of blood from a healthy volunteer donor, using Ficoll-Paque PLUS (GE Healthcare Life Sciences, Pittsburgh, PA, USA). Cells were maintained in RPMI-1640 medium (Life Technologies) supplemented with 10\% fetal bovine serum (FBS; Life Technologies) and 1\% antibiotic-antifungal solution (Life Technologies), whereas MCF-7 cells were grown in Dulbecco's modified Eagle medium (DMEM; Life Technologies) supplemented with 10\% FBS and 1\% antibiotic-antifungal solution (Life Technologies) (complete culture medium). Cells were cultured at $37^{\circ} \mathrm{C}$ in an atmosphere of $5 \% \mathrm{CO}_{2}$.

\subsection{Effect of Endophytic Fungus Strain Extracts on Murine and Human Tumor Cell Growth}

L5178Y-R, HT-29, MCF-7, and MA-104 cell suspensions were cultured at density of $1 \times 10^{4}$ cells/well and PBMCs at $1 \times 10^{5}$ cells / well into flat-bottomed 96-well plates (Corning Incorporated, Corning, NY, USA) in complete culture medium. After $24 \mathrm{~h}$ of incubation, cells were treated with $31 \mu \mathrm{g} / \mathrm{mL}, 62.5 \mu \mathrm{g} / \mathrm{mL}, 125 \mu \mathrm{g} / \mathrm{mL}$, and $250 \mu \mathrm{g} / \mathrm{mL}$ of endophytic fungus methanol extracts for $48 \mathrm{~h}$ at $37^{\circ} \mathrm{C}$ in $5 \% \mathrm{CO}_{2}$. Tumor cell growth was then evaluated using the colorimetric 3- [4,5-dimethylthiazol-2-yl]-2,5-diphenyltetrazoliumbromide (MTT; Affymetrix, Cleveland, OH, USA) reduction assay by adding $15 \mu \mathrm{L}$ of MTT $(0.5 \mathrm{mg} / \mathrm{mL}$ final concentration) and incubating at $37^{\circ} \mathrm{C}$ for an additional $4 \mathrm{~h}$. Formazan crystals were dissolved with DMSO, and optical densities (OD) were measured at $570 \mathrm{~nm}$ in a MULTISKAN GO microplate reader (Thermo Fisher Scientific, Waltham, MA, USA). Cell growth inhibition percentage was calculated as follows: \% Growth inhibition $=100-\left[\mathrm{OD}_{570}\right.$ in extract-treated cells $/ \mathrm{OD}_{570}$ in untreated cells) (100)], using $0.05 \mu \mathrm{g} / \mathrm{mL}$ vincristine sulphate (VC; Hospira, Warwickshire, UK) as a positive control. Logarithmic scale concentrations were plotted against \% cytotoxicity to determine $\mathrm{IC}_{50}$ values, which were used to determine the selectivity index (SI). This index was calculated by dividing the $\mathrm{IC}_{50}$ of normal cells by that of tumor cells [20].

\subsection{Molecular Identification of L. marginatus Endophytic fungi}

Genomic DNA extraction was performed from monosporic cultures, using cetyl trimethylammonium bromide (CTAB; Sigma-Aldrich, St. Louis, MO, USA) as reported by Kuramane-Izioka [21]. Purified DNA was then subjected to a PCR with the universal markers ITS1 (5'-TCCGTAGGTGAACCTGCGG-3') and ITS4 (5'-TCCTCCGCTTATTGATATGC$3^{\prime}$ ) in a volume of $50 \mu \mathrm{L}$, using the Ruby Taq Master mix 2X (Jena Bioscience, Jena, Germany), $100 \mathrm{ng}$ of the DNA template, and $0.25 \mu \mathrm{M}$ of each primer. The amplification program consisted of a denaturation cycle of $95^{\circ} \mathrm{C}$ for $5 \mathrm{~min}, 35$ cycles of $94{ }^{\circ} \mathrm{C}$ for $30 \mathrm{~s}, 60{ }^{\circ} \mathrm{C}$ for $45 \mathrm{~s}$, and $72{ }^{\circ} \mathrm{C}$ for $90 \mathrm{~s}$, followed by a final extension of $72{ }^{\circ} \mathrm{C}$ for $8 \mathrm{~min}$ [22]. The PCR product was purified with the Agarose Gel Extraction kit (Jena Bioscience). The product was then sequenced with the ABI PRISM 310 TM Genetic Analyzer sequencer at the Synthesis and Sequencing Unit of the Institute of Biotechnology (IBT) of the UNAM in Cuernavaca Morelos. Sequence analysis was performed using the National Center for Biotechnology Information database via the BLASTn tool [https:/ / blast.ncbi.nlm.nih.gov/Blast.cgi (accessed on 9 February 2021)] to identify the closest fungal species. The assigned names of fungal isolates were based on the BLAST homology percentages. 


\subsection{Statistical Analysis}

Cytotoxicity results were expressed as mean \pm SEM of triplicate determinations from three independent experiments. Level of significance was evaluated by the Dunnet's $t$ test. $\mathrm{IC}_{50}$ values were reported with $95 \%$ confidence intervals (95\% CI). Statistical analyses were performed using the Graph Pad Prism 7 program.

\section{Results}

\subsection{Isolation of L. marginatus Endophytic Fungi}

We isolated filamentous fungi from L. marginatus stems, but only data of endophytic fungus strains with cytotoxic activity are shown (strains PME-H001, PME-H002, PMEH005, PME-H007, and PME-H008). Isolates were morphologically characterized, with most of them showing circular shape, filamentous edge, and flat mycelium. Radial growth at $3 \mathrm{~d}$ and $7 \mathrm{~d}$ was from $5.1 \mathrm{~mm}$ to $8.5 \mathrm{~mm}$ and $9.9 \mathrm{~mm}$ to $22.6 \mathrm{~mm}$, respectively. Isolates first fermented in PDB, after which biomass methanol extraction was performed, obtaining yields ranging from $5.2 \%$ to $12 \%$ (Table 1 ).

Table 1. Morphological characterization and extract yields of L. marginatus endophytic fungi with cytotoxic activity.

\begin{tabular}{|c|c|c|c|c|c|c|c|c|}
\hline \multirow{2}{*}{ Isolate Code } & \multicolumn{2}{|c|}{ Radial Growth (mm) } & \multirow{2}{*}{ Shape } & \multirow{2}{*}{ Edge } & \multirow{2}{*}{ Mycelium } & \multirow{2}{*}{ Topside Color * } & \multirow{2}{*}{ Underside Color * } & \multirow{2}{*}{$\begin{array}{c}\text { Extract } \\
\text { Yield }\end{array}$} \\
\hline & $3 \mathrm{~d}$ & $7 \mathrm{~d}$ & & & & & & \\
\hline PME-H001 & 7.3 & 9.9 & Circular & Filamentous & Flat & \# 838B83 & \#F0E68C/EEF3E2 & $5.2 \%$ \\
\hline PME-H002 & 8.5 & 17.5 & Circular & Filamentous & Flat & \#838B83 & \#F0E68C/EEF3E2 & $5.2 \%$ \\
\hline PME-H005 & 8.1 & 17.9 & Circular & Irregular & Flat & \#838B83 & \#FFC125/FEF0C9 & $12 \%$ \\
\hline PME-H007 & 6.2 & 22.6 & Circular & Filamentous & Flat & \#006400/FFFFFF & \#CD9B10/EEDC82 & $8.9 \%$ \\
\hline PME-H008 & 5.1 & 15.2 & Circular & Entire & Flat & \#2F4F4F/EBECE4 & \#FEFEF2 & $5.6 \%$ \\
\hline
\end{tabular}

* The colors of the colonies were defined using the color chart on the webpage http://www.webusable.com/coloursTable.htm (accessed on 9 February 2021).

\subsection{Effect of L. marginatus Endophytic Fungi Extracts on Tumor Cell Growth}

Fungal methanol extracts were evaluated at concentrations ranging from $31 \mu \mathrm{g} / \mathrm{mL}$ to $250 \mu \mathrm{g} / \mathrm{mL}$ against the tumor cell lines L5178Y-R, HT-29, and MCF-7, and the normal cells MA-104 and PBMCs. PME-H001, PME-H002, PME-H005, PME-H007, and PME-H008 filamentous fungus strains showed significant $(p<0.05)$ tumor cell growth inhibition (Figure 1). Extracts were effective against L5178Y-R cells, whereas the least susceptible cell line was HT-29. PME-H008 extract caused the highest growth inhibition percentage against L5178Y-R and HT-29 cells with $96.6 \%(p<0.01)$ and $42.5 \%(p<0.05)$ respectively, whereas PME-H007 extract caused the highest growth inhibition percentage $(p<0.01)$ against MCF-7 cells with $55.8 \%$ at $250 \mu \mathrm{g} / \mathrm{mL}$. Regarding $\mathrm{IC}_{50}$, PME-H005 extract showed the lowest values with $95.21 \mu \mathrm{g} / \mathrm{mL}$ against the MCF-7 cell line, followed by PME-H008 with $101 \mu \mathrm{g} / \mathrm{mL}$ against L5178Y-R cells. In addition, extracts showed an $\mathrm{IC}_{50}$ higher than $291 \mu \mathrm{g} / \mathrm{mL}$ against the HT-29 cell line, whereas the lowest percentage of growth inhibition was observed for PME-H001 and PME-H002 extracts with respective $\mathrm{IC}_{50}$ values of $437.7 \mu \mathrm{g} / \mathrm{mL}$ against MA-104 cells and $409.8 \mu \mathrm{g} / \mathrm{mL}$ against PBMCs (Figure 1). In addition, PME-H008 extract showed the highest SIs against L5178Y-R cells with values of 2.4 and 2.9, compared with MA-104 and PBMCs, respectively, whereas PME-H005 extract showed SIs of 2.77 and 1.5 against MCF-7 and L5178Y-R cells, respectively, compared with PBMCs (Table 2). $\mathrm{IC}_{50}$ values outside the highest concentration used $(250 \mu \mathrm{g} / \mathrm{mL})$ shown in Table 2 were determined using the Prisma software v.9. In this regard, when extract concentration that induces $50 \%$ growth inhibition was not reached or it may be found outside the highest concentration tested, this software facilitates its calculation. We did not evaluate higher than $250 \mu \mathrm{g} / \mathrm{mL}$ concentrations of the extracts due to their limited availability. 
(a)

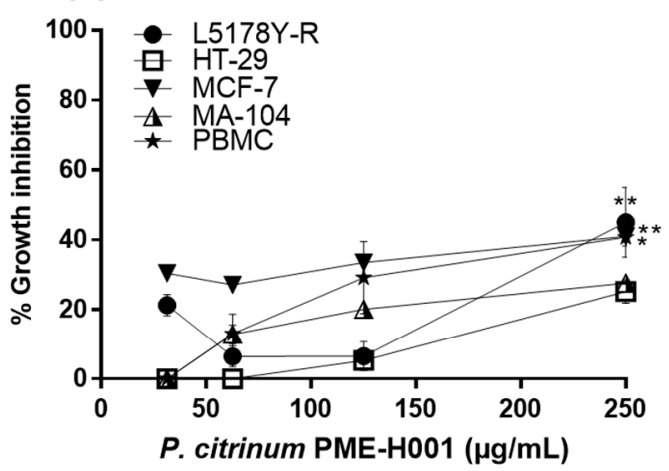

(c)

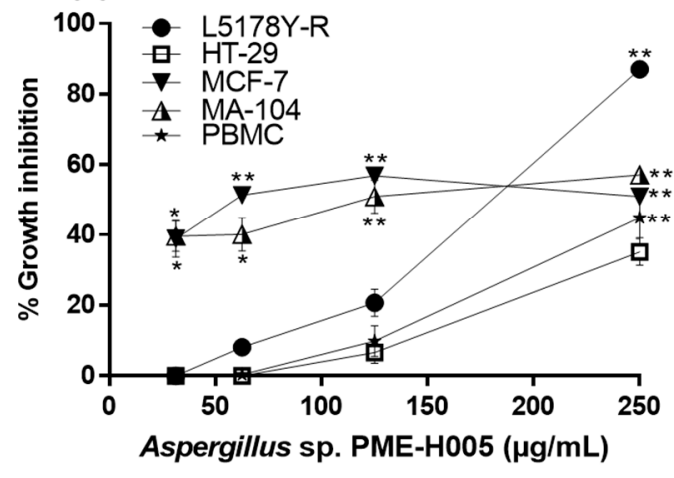

(b)

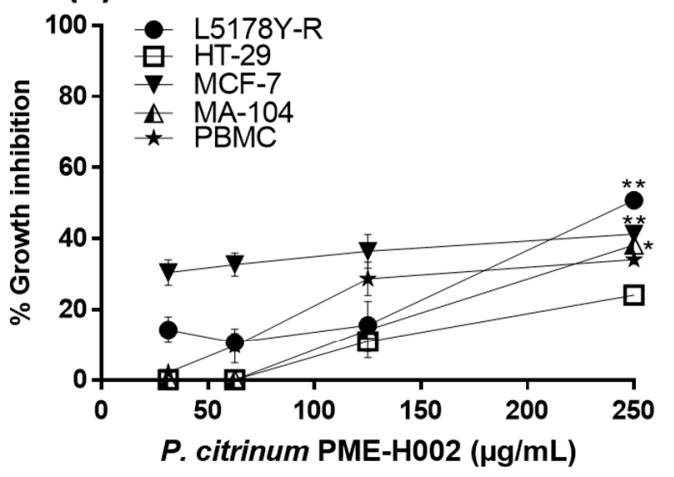

(d)

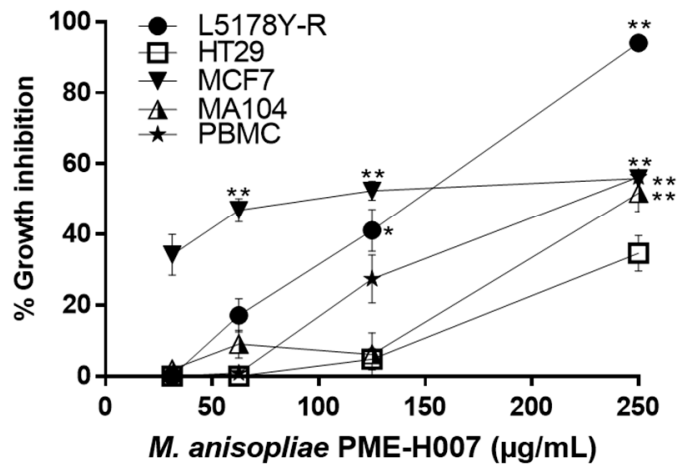

(e)

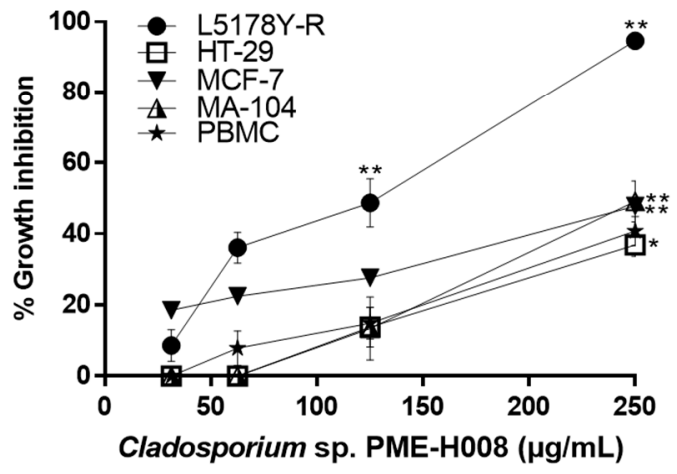

Figure 1. Tumor growth inhibition by L. marginatus endophytic fungus methanol extracts. L5178Y-R, HT-29, MCF-7, and MA-104 cells at $1 \times 10^{4}$ cells/well and PBMCs at $1 \times 10^{5}$ cells/well were incubated for $24 \mathrm{~h}$ and treated for 48 with $31 \mu \mathrm{g} / \mathrm{mL}$ to $250 \mu \mathrm{g} / \mathrm{mL}$ of (a) PME-H001, (b) PME-H002, (c) PME-H005, (d) PME-H007, and (e) PME-H008 fungus strain methanol extracts, as detailed in the text. Cell growth inhibition was evaluated via the MTT reduction assay and ODs measured at $570 \mathrm{~nm}$, using $0.05 \mu \mathrm{g} / \mathrm{mL}$ vincristine sulphate (VC) as a positive control, as detailed in the text. VC caused 77.4\%, 46.8\%, 14.3\%, 24\%, and 14.7\% cytotoxicity against L5178Y-R, HT-29, MCF-7, MA-104, and PBMCs, respectively. Data represent mean \pm SEM of triplicates from three independent experiments. ${ }^{*} p<0.05 ;{ }^{* *} p<0.01$, as compared with untreated control. OD for untreated control was $1.39 \pm 0.12$. 
Table 2. $\mathrm{IC}_{50}{ }^{\mathrm{a}}$ and SI of tumor cell lines and MA-104 and PBMCs treated with fungus methanol extracts.

\begin{tabular}{|c|c|c|c|c|c|c|c|c|c|c|}
\hline \multirow{2}{*}{$\begin{array}{c}\text { Isolate } \\
\text { Code. }\end{array}$} & \multicolumn{2}{|c|}{ L5178Y-R } & \multicolumn{2}{|c|}{ HT-29 } & \multicolumn{2}{|c|}{ MCF-7 } & \multicolumn{2}{|c|}{ MA-104 } & \multicolumn{2}{|c|}{ PBMCs } \\
\hline & $\mathrm{IC}_{50}{ }^{\mathrm{a}}$ & SI * & $\mathrm{IC}_{50}$ & SI & $\mathrm{IC}_{50}$ & SI & $\mathrm{IC}_{50}$ & SI & $\mathrm{IC}_{50}$ & SI \\
\hline PME-H001 & $269.4 \pm 1.4$ & $1.6 / 1^{b}$ & $348.1 \pm 1.1$ & $1.2 / 0.8$ & $1387 \pm 0.7$ & $0.3 / 0.2$ & $437.7 \pm 0.8$ & 1 & $295.4 \pm 1.2$ & 1 \\
\hline PME-H002 & $266.5 \pm 1.4$ & $1.1 / 1.5$ & $402.5 \pm 1$ & $0.7 / 1$ & $1244 \pm 0.6$ & $0.2 / 0.3$ & $295.4 \pm 1.4$ & 1 & $409.8 \pm 1.2$ & 1 \\
\hline PME-H005 & $166.2 \pm 1.8$ & $0.7 / 1.5$ & $291.6 \pm 1.2$ & $0.4 / 0.9$ & $95.21 \pm 1$ & $1.2 / 2.77$ & $123.5 \pm 1.3$ & 1 & $264 \pm 1.5$ & 1 \\
\hline PME-H007 & $132.9 \pm 1.5$ & $1.8 / 0.7$ & $291.7 \pm 1.3$ & $0.8 / 0.7$ & $114.7 \pm 1.3$ & $2.1 / 1.8$ & $245.9 \pm 1.9$ & 1 & $215.8 \pm 1.6$ & 1 \\
\hline PME-H008 & $101 \pm 1.5$ & $2.4 / 2.9$ & $301.1 \pm 1.2$ & $0.8 / 0.9$ & $337.5 \pm 1.3$ & $0.7 / 0.8$ & $250.2 \pm 1.2$ & 1 & $298.8 \pm 1.4$ & 1 \\
\hline
\end{tabular}

${ }^{a}$ Values are provided in $\mu \mathrm{g} / \mathrm{mL} ;{ }^{b}$ SI of MA-104/PBMC compared with fungus strain extracts; ${ }^{*} \mathrm{SI}=\mathrm{IC}_{50}$ of MA-104 or PBMC/IC 50 of tumor cell lines.

\subsection{Molecular Identification of L. marginatus Endophytic Fungi with Cytotoxic Activity}

We performed molecular identification of endophytic fungi that showed cytotoxic activity against the tumor cell lines L5178Y-R, HT-29, and MCF-7 (Figure 1). The amplified regions (ITS1/ITS4) were sequenced, manually reviewed, and analyzed using the Blast tool for fungal identification. PME-H001 and PME-H002 isolates were identified as Penicillium citricum with $99.6 \%$ and $99.2 \%$ identity, respectively (Table 3). PME-H005 and PME-H008 were only identified up to the genus level as Aspergillus sp. with $99 \%$ and Cladosporium sp. with 97.6\%, whereas PME-H007 was identified as Metarhizium anisopliae with $98.9 \%$ identity (Table 3).

Table 3. Molecular identification based on ITS1/TS4 sequences of cytotoxic L. marginatus endophytic fungi.

\begin{tabular}{|c|c|c|c|c|c|}
\hline Isolate Code & Closest Relatives in NCBI & Query Cover & E-Value & Percent Identity & Classification \\
\hline PME-H001 & $\begin{array}{l}\text { Penicillium citrinum strain } \\
\text { IBB_40 (MH793859.1) }\end{array}$ & $97 \%$ & 0.0 & $99.6 \%$ & Penicillium citrinum \\
\hline PME-H002 & $\begin{array}{l}\text { Penicillium citrinum strain } \\
\text { MEBP0016 (MT597829.1) }\end{array}$ & $100 \%$ & $6 \times 10^{-131}$ & $99.2 \%$ & Penicillium citrinum \\
\hline \multirow[t]{2}{*}{ PME-H005 } & $\begin{array}{c}\text { Aspergillus tabacinus } \\
\text { (MT635280.1) }\end{array}$ & $100 \%$ & $2 \times 10^{-47}$ & $99 \%$ & \multirow[t]{2}{*}{ Aspergillus sp. } \\
\hline & $\begin{array}{l}\text { Aspergillus versicolor strain } \\
\text { HM65 (MT609910.1) }\end{array}$ & $100 \%$ & $2 \times 10^{-47}$ & $99 \%$ & \\
\hline PME-H007 & $\begin{array}{l}\text { Metarhizium anisopliae isolate } \\
\text { CENIEN041 (HQ722915.1) }\end{array}$ & $98 \%$ & 0.0 & $98.9 \%$ & $\begin{array}{l}\text { Metarhizium } \\
\text { anisopliae }\end{array}$ \\
\hline PME-H008 & $\begin{array}{c}\text { Cladosporium sp. isolate } \\
\text { 978-SAB SA4 } 2 \\
\text { (MT820353.1) }\end{array}$ & $98 \%$ & 0.0 & $97.6 \%$ & Cladosporium sp. \\
\hline
\end{tabular}

\section{Discussion}

Endophytic fungi represent an important source of biologically active compounds, including phenolic acids, alkaloids, quinones, steroids, saponins, tannins, and terpenoids with antidiabetic, anti-inflammatory, antiviral, immunosuppressive, anti-arthritis, antioxidant, antimicrobial, and anticancer effects [23]. However, less than $16 \%$ of fungal species have been cultured and studied and less than $5 \%$ of them represent important sources of bioactive metabolites [24]. The distribution of certain populations of endophytic fungi is restricted to a species or a family of plants, as well as to the genotype of the species. Thus, the presence of a specific population of fungi may determine the production of a variety of secondary metabolites [25]. Medicinal plants harbor endophytic fungi with the potential to produce pharmaceutically important products [26] due to the continuous metabolic interaction between fungus and plant, which may result in the production of similar compounds following similar metabolic pathways. For this reason, it is important to select plant species for the isolation of endophytic fungi in search of bioactive agents [27].

Therefore, this study reports the cytotoxic activity of endophytic fungi isolated from the medicinal plant L. marginatus, a species of cactus endemic to Mexico, which was previously reported to possess antitumor potential [16-18]. In the present study, we 
isolated Penicillium, Aspergillus, and Cladosporium genera, which are commonly obtained from plants that inhabit dry environments, such as cacti $[19,28,29]$, whereas Metarhizium has been reported as a natural endophyte of Glycine [30], Taxus [31], Brassica, Secale, and Avena genera [32]. This study also showed Metarhizium as an endophyte of cacti.

Anticancer resistance is a serious problem in oncology, as in the case of breast cancer [33], colon cancer [34], and non-Hodgkin lymphoma [35]. Therefore, it is essential to search for and identify new compounds with cytotoxic activity, against which cancer cells are not resistant [36]. Various endophytic fungi have shown anticancer effects against hepatoma (HepG2), lung cancer (A-549), colorectal cancer (HCT-116, HT-29), breast cancer (MCF7), ovarian cancer (SKVO3), leukemia (HL-60), carcinoma (KB), cervical cancer (Hela), and lymphoma (L5178Y) [4].

The isolated strains of P. citrinum, PME-H001 and PME-H002, showed comparable cytotoxic activity, probably due to the production of similar compounds, however the metabolite profiles must be analyzed for confirmation. On the other hand, the anticancer activity of this species has been reported against different tumor cell lines, including A549, Hela, HepG2, L5178Y, MOLT-4, MCF-7, BT-474, and MDA-MB-231 and different compounds have been identified as being responsible for this activity, such as penicillocitrin A, 2-(2-acetyl-hydrazinyl) benzoic acid, 2-pyruvoylaminobenzamide, secalonic acid A, citriquinochroman, pyrrolidine alkaloids, pencitrin, and penicitrinone E [37-41]. In our study, Cladosporium sp. methanol extract caused moderate cytotoxicity against MCF-7 cells, whereas a report by Raj et al. [42] showed the activity of taxol obtained from C. oxysporum extracts against the T47D breast cancer cell line, with an $\mathrm{IC}_{50}$ value of $2.5 \mu \mathrm{M}$ after $24 \mathrm{~h}$ of incubation.

Fungi of the genus Aspergillus are considered important sources of bioactive compounds with anticancer activity, among which are alkaloids, pyrones, polyketides, lactones, sterols, xanthones, anthraquinones, terpenes, peptides, depsipeptides, cyclic peptides, cytochalasins, enzymes, and proteins. They have been evaluated in different tumor cell lines such as MCF-7, HL-60, K-562, A549, MOLT-4, and HEP-G2 [43]. Furthermore, the potential of $M$. anisopliae to produce anticancer compounds such as taxol, with yields of $846.1 \mu \mathrm{g} / \mathrm{L}$ in liquid medium [31], and destruxin B, with $\mathrm{IC}_{50}$ values of $4.9 \mu \mathrm{M}$ in $\mathrm{A} 549$ lung cancer cells, has been previously demonstrated [44].

Most anticancer drugs affect cancer and normal cells. Thus, researchers attempt to develop new drugs that are selective for cancer cells with minimal effects on other cells [5]. Determining the SI value results an essential tool for evaluating potential antitumor agents with limited toxicity to normal cells [45]. For evaluating any anticancer activity of a sample, its cytotoxicity against nonmalignant cells must be determined through the SI $[45,46]$. In our study, PME-H008 extract showed SI values of 2.4 and 2.9 against L5178Y-R cells, compared with MA-104 and PBMCs respectively, whereas SIs of PME-H005 extract against MCF-7 and L5178Y-R cells were 2.77 and 1.5 respectively, as compared with PBMCs (Table 2), which may represent prospective anticancer samples that warrant further investigation $[45,47]$. Endophytic fungi may play an important role in providing chemotherapeutic compounds with high specificity and minimal side effects.

\section{Conclusions}

The search for endophytic fungi from different habitats may provide an opportunity to discover new drugs and their application in human diseases. Evaluation of L. marginatus endophytic fungi methanol extracts have revealed their potential as producers of bioactive compounds with antitumor potential.

Author Contributions: Conceptualization, P.T.-G.; Data curation, C.I.R.-S. and R.T.-G.; Formal analysis, C.I.R.-S., C.R.-P., R.T.-G. and A.A.O.-F.; Funding acquisition, Ricardo Gomez-Flores and P.T.-G.; Investigation, J.M.R.-V. and R.R.-A.; Methodology, C.I.R.-S., J.M.R.-V., K.S.M.-S., R.Q.-L., A.A.O.-F. and R.R.-A.; Project administration, R.G.-F.; Resources, R.G.-F., R.Q.-L., C.R.-P. and R.T.G.; Software, J.M.R.-V. and A.A.O.-F.; Supervision, R.G.-F., K.S.M.-S., P.T.-G., R.Q.-L. and C.R.-P.; 
Validation, C.I.R.-S.; Writing—original draft, J.M.R.-V.; Writing-review and editing, R.G.-F. All authors have read and agreed to the published version of the manuscript.

Funding: This study was supported by Grant CN1235-20 from Programa de Apoyo a la Investigación Científica y Tecnológica-UANL to R.G.-F.

Institutional Review Board Statement: The investigations were carried out following the rules of the Declaration of Helsinki of 1975 (https: / / www.wma.net/what-we-do/medical-ethics/declarationof-helsinki/ (accessed on 9 February 2021)), revised in 2013.

Informed Consent Statement: Written informed consent was obtained from one healthy volunteer, who provided $20 \mathrm{~mL}$ to $30 \mathrm{~mL}$ peripheral blood for each experiment (three experiments were performed).

Data Availability Statement: The datasets generated and/or analyzed during the present study are available from the corresponding author on reasonable request.

Acknowledgments: We would like to thank the Laboratorio de Inmunología y Virología of Facultad de Ciencias Biológicas at Universidad Autónoma de Nuevo León for supporting this study.

Conflicts of Interest: The authors declare no conflict of interest.

\section{References}

1. International Agency for Research on Cancer. Section of Cancer Surveillance. Available online: http:/ / gco.iarc.fr/ (accessed on 21 March 2021).

2. Ganesh, K.; Massagué, J. Targeting metastatic cancer. Nat. Med. 2021, 27, 34-44. [CrossRef]

3. Dickens, E.; Ahmed, S. Principles of cancer treatment by chemotherapy. Surgery 2018, 36, 134-138. [CrossRef]

4. Rajamanikyam, M.; Vadlapudi, V.; Amanchy, R.; Upadhyayula, S.M. Endophytic fungi as novel resources of natural therapeutics. Braz. Arch. Biol. Technol. 2017, 60, 1678-4324. [CrossRef]

5. Kharwar, R.N.; Mishra, A.; Gond, S.K.; Stierle, A.; Stierle, D. Anticancer compounds derived from fungal endophytes: Their importance and future challenges. Nat. Prod. Rep. 2011, 28, 1208-1228. [CrossRef] [PubMed]

6. Yu, H.; Zhang, L.; Li, L.; Zheng, C.; Guo, L.; Li, W.; Sun, P.; Qin, L. Recent developments and future prospects of antimicrobial metabolites produced by endophytes. Microbiol. Res. 2010, 165, 437-449. [CrossRef]

7. Bezerra, J.D.P.; Santos, M.G.S.; Svedese, V.M.; Lima, D.M.M.; Fernandes, M.J.S.; Paiva, L.M.; Souza, M.C.M. Richness of endophytic fungi isolated from Opuntia ficus-indica Mill. (Cactaceae) and preliminary screening for enzyme production. World J. Microbiol. Biotechnol. 2012, 28, 1989-1995. [CrossRef]

8. Ratnaweera, P.B.; de Silva, E.D.; Williams, D.E.; Andersen, R.J. Antimicrobial activities of endophytic fungi obtained from the arid zone invasive plant Opuntia dillenii and the isolation of equisetin, from endophytic Fusarium sp. BMC Complement. Altern. Med. 2015, 15, 220. [CrossRef]

9. Zhan, J.; Burns, A.M.; Liu, M.X.; Faeth, S.H.; Gunatilaka, A.L. Search for cell motility and angiogenesis inhibitors with potential anticancer activity: Beauvericin and other constituents of two endophytic strains of Fusarium oxysporum. J. Nat. Prod. 2007, 70, 227-232. [CrossRef]

10. Li, C.; Wang, F.; Wu, X.; Cao, S. A new 24-homo-30-nor-cycloartane triterpenoid from a Hawaiian endophytic fungal strain. Tetrahedron. Lett. 2019, 61, 151508. [CrossRef]

11. Fouda, A.H.; Hassan, S.E.D.; Eid, A.M.; Ewais, E.E.D. Biotechnological applications of fungal endophytes associated with medicinal plant Asclepias sinaica (Bioss.). Ann. Agric. Sci. 2015, 60, 95-104. [CrossRef]

12. Hernández, H.M.; Gómez, H.C.; Goettsch, B. Checklist of Chihuahuan Desert Cactaceae. Harv. Pap. Bot. 2004, 9, 51-68.

13. Hernández, T.; Canales, M.; Avila, J.G.; Duran, A.; Caballero, J.; De Vivar, A.R.; Lira, R. Ethnobotany and antibacterial activity of some plants used in traditional medicine of Zapotitlán de las Salinas, Puebla (México). J. Ethnopharmacol. 2003, 88, 181-188. [CrossRef]

14. Johnson, L.; Strich, H.; Taylor, A.; Timmermann, B.; Malone, D.; Teufel, S.N.; Drummond, R.; Woosley, R.; Pereira, E.; Martinez, A. Use of herbal remedies by diabetic Hispanic women in the southwestern United States. Phytother. Res. 2006, 20, $250-255$. [CrossRef] [PubMed]

15. Moreno, L.S.; González, M.P.B.; Herrera, I.M.; Gutiérrez, Y.Q.; Arredondo, J.L.M.; Rodríguez, R.G. In vitro inhibition of Helicobacter pylori by methanolic extract of Stenocereus marginatus and Castela texana. Int. J. Med. Plant Altern. Med. 2015, 3, 10-17.

16. Hernández, M.H.C.; Gomez, F.R.; Tamez, G.P.; Quintanilla, L.R.; Escamilla, M.Á.S.; Monreal, C.E.; Rodriguez, P.C. Antitumor activity of Pachycereus marginatus (DC.) Britton Rose extracts against murine lymphoma L5178Y-R and skin melanoma B16F10 cells. J. Med. Plant Res. 2016, 10, 635-639.

17. Quintanilla, L.R.; Gomez, F.R.; Samanieg, E.M.Á.; Hernández, M.H.C.; Tamez, G.P.; Morado, C.R. Cytotoxic Effect of Methanol Extracts and Partitions of Two Mexican Desert Plants against the Murine Lymphoma L5178Y-R. Am. J. Plant Sci. 2016, 7, 1521-1530. [CrossRef] 
18. Gomez, F.R.; Quintanilla, L.R.; Hernández, M.H.C.; Samaniego, E.M.; Tamez, G.P.; Monreal, C.E.; Rodriguez, P.C. Survival of lymphoma-bearing mice by Pachycereus marginatus cactus extracts and elucidation of bioactive compounds. Nat. Prod. Commun. 2019, 14, 1-6.

19. Bezerra, J.D.; Santos, M.G.; Barbosa, R.N.; Svedese, V.M.; Lima, D.M.; Fernandes, M.J.S.; Souza, M.C.M. Fungal endophytes from cactus Cereus jamacaru in Brazilian tropical dry forest: A first study. Symbiosis 2013, 60, 53-63. [CrossRef]

20. Singh, K.; Gangrade, A.; Jana, A.; Mandal, B.B.; Das, N. Design, Synthesis, characterization, and antiproliferative activity of organoplatinum compounds bearing a 1, 2, 3-triazole ring. ACS Omega 2019, 4, 835-841. [CrossRef]

21. Valdés, L.A.; Gómez, A.; Carballo, M.E.; Capote-del Sol, M.; González, I.; Rohde, W. Estandarización de protocolos para la extracción de ADN cromosómico en cepas de Colletotrichum gloeosporioides aislados en plantas de mango (Mangifera indica L.). La Granja Revista de Ciencias de la Vida 2015, 22, 40-49.

22. White, T.J.; Bruns, T.; Lee, S.; Taylor, J. Amplification and direct sequencing of fungal ribosomal RNA genes for phylogenetics. In PCR Protocols: A Guide to Methods and Applications; Innis, A., Gelfand, D.H., Sninsky, J.J., White, T.J., Eds.; Academic Press: San Diego, CA, USA, 1990; pp. 315-322.

23. Naik, B.S. Potential roles for endophytic fungi in biotechnological processes: A review. In Plant and Human Health; Ozturk, M., Hakeem, K.R., Eds.; Springer: Cham, Switzerland, 2019; pp. 327-344.

24. Bedi, A.; Adholeya, A.; Deshmukh, S.K. Novel anticancer compounds from endophytic fungi. Curr. Biotechnol. 2018, 7, 168-184. [CrossRef]

25. Dai, C.C.; Yu, B.Y.; Xu, Z.L.; Yuan, S. Effect of environmental factors on growth and fatty acid composition of five endophytic fungi from Sapium sebiferum. J. Appl. Ecol. 2003, 14, 1525-1528.

26. De Carvalho, C.R.; Ferreira, M.C.; Amorim, S.S.; da Silva, F.R.H.; De Assis, J.C.S.; Zani, C.L.; Rosa, L.H. Bioactive compounds of endophytic fungi associated with medicinal plants. In Recent Advancement in White Biotechnology Through Fungi; Yadav, A.N., Singh, S., Mishra, S., Gupta, A., Eds.; Springer: Cham, Switzerland, 2019; pp. 303-361.

27. Chandra, S. Endophytic fungi: Novel sources of anticancer lead molecules. Appl. Microbiol. Biotechnol. 2012, 95, 47-59. [CrossRef] [PubMed]

28. Bezerra, J.D.P.; de Azevedo, J.L.; Souza, M.C.M. Why study endophytic fungal community associated with cacti species? In Diversity and Benefits of Microorganisms from the Tropics; De Azevedo, J.L., Quecine, M.C., Eds.; Springer: Cham, Switzerland, 2017; pp. 21-35.

29. Santos, M.D.S.; Bezerra, J.D.P.; Svedese, V.M.; Sousa, M.A.; da Silva, D.C.V.; Maciel, M.D.H.C.; Paiva, L.M.; Porto, A.L.F.; de Souza, C.M. Screening of endophytic fungi from cactus of the Brazilian tropical dry forest according to their L-asparaginase activity. Sydowia 2015, 67, 147-156.

30. Khan, A.L.; Hamayun, M.; Khan, S.A.; Kang, S.M.; Shinwari, Z.K.; Kamran, M.; Rehman, S.; Kim, J.G.; Lee, I.J. Pure culture of Metarhizium anisopliae LHL07 reprograms soybean to higher growth and mitigates salt stress. World J. Microbiol. Biotechnol. 2012, 28, 1483-1494. [CrossRef] [PubMed]

31. Liu, K.; Ding, X.; Deng, B.; Chen, W. Isolation and characterization of endophytic taxol-producing fungi from Taxus chinensis. J. Ind. Microbiol. Biotechnol. 2009, 36, 1171-1177. [CrossRef]

32. Steinwender, B.M.; Enkerli, J.; Widmer, F.; Eilenberg, J.; Kristensen, H.L.; Bidochka, M.J.; Meyling, N.V. Root isolations of Metarhizium spp. from crops reflect diversity in the soil and indicate no plant specificity. J. Invertebr. Pathol. 2015, 132, 142-148. [CrossRef]

33. Lee, H.E.; Kim, J.H.; Kim, Y.J.; Choi, S.Y.; Kim, S.W.; Kang, E.; Chung, I.Y.; Kim, I.A.; Kim, E.J.; Choi, Y.; et al. An increase in cancer stem cell population after primary systemic therapy is a poor prognostic factor in breast cancer. Br. J. Cancer. 2011, 104, 1730-1738. [CrossRef]

34. Hu, T.; Li, Z.; Gao, C.Y.; Cho, C.H. Mechanisms of drug resistance in colon cancer and its therapeutic strategies. World J. Gastroenterol. 2016, 22, 6876. [CrossRef]

35. Klener, P.; Klanova, M. Drug resistance in non-Hodgkin lymphomas. Int. J. Mol. Sci. 2020, 21, 2081. [CrossRef]

36. Falzone, L.; Salomone, S.; Libra, M. Evolution of cancer pharmacological treatments at the turn of the third millennium. Front. Pharmacol. 2018, 9, 1300. [CrossRef]

37. Danagoudar, A.; Joshi, C.G.; Ravi, S.K.; Kumar, H.G.R.; Ramesh, B.N. Antioxidant and cytotoxic potential of endophytic fungi isolated from medicinal plant Tragia involucrata L. Pharmacogn. Res. 2018, 10, 188-194.

38. Li, X.; Zhang, L.; Liu, Y.; Guo, Z.; Deng, Z.; Chen, J.; Zou, K. A new metabolite from the endophytic fungus Penicillium citrinum. Nat. Prod. Commun. 2013, 8, 587-588. [CrossRef]

39. El-Neketi, M.; Ebrahim, W.; Lin, W.; Gedara, S.; Badria, F.; Saad, H.E.A.; Lai, D.; Proksch, P. Alkaloids and polyketides from Penicillium citrinum, an endophyte isolated from the Moroccan plant Ceratonia siliqua. J. Nat. Prod. 2013, 76, 1099-1104. [CrossRef] [PubMed]

40. Mady, M.; Wael, W.; Abdou, R.; Haggag, E.; El Sayed, K. Breast cancer migration and proliferation inhibitory and antibiotic secondary metabolites from the Egyptian olive tree endophytic fungus Penicillium citrinum. J. Adv. Pharm. Res. 2017, 1, 160-170. [CrossRef]

41. Hu, Y.; Zhang, J.; Liu, D.; Guo, J.; Liu, T.; Xin, Z. Pencitrin and pencitrinol, two new citrinin derivatives from an endophytic fungus Penicillium citrinum salicorn 46. Phytochem. Lett. 2017, 22, 229-234. [CrossRef] 
42. Raj, K.G.; Sambantham, S.; Manikanadan, R.; Arulvasu, C.; Pandi, M. Fungal taxol extracted from Cladosporium oxysporum induces apoptosis in T47D human breast cancer cell line. Asian Pac. J. Cancer Prev. 2014, 15, 6627-6632. [CrossRef] [PubMed]

43. Nadumane, V.K.; Venkatachalam, P.; Gajaraj, B. Aspergillus applications in cancer research. In New and Future Developments in Microbial Biotechnology and Bioengineering; Rastegari, A.A., Yadav, A.N., Yadav, N., Eds.; Elsevier: Edinburgh, UK, 2016; pp. 243-255.

44. Wu, C.C.; Chen, T.H.; Liu, B.L.; Wu, L.C.; Chen, Y.C.; Tzeng, Y.M.; Hsu, S.L. Destruxin B isolated from entomopathogenic fungus Metarhizium anisopliae induces apoptosis via a Bcl-2 family-dependent mitochondrial pathway in human nonsmall cell lung cancer cells. Evid.-Based Complement. Altern. Med. 2013, 2013, 548929. [CrossRef]

45. Indrayanto, G.; Putra, G.S.; Suhud, F. Validation of in-vitro bioassay methods: Application in herbal drug research. Profiles Drug Subst. Excip. Relat. Methodol. 2020, 46, 273-307.

46. Wardihan; Rusdi, M.; Alam, G.; Muslimin, L.; Manggau, M. Selective Cytotoxicity evaluation in Anticancer drug screening of Boehmeria virgata (Forst) Guill leaves to several huma cell lines: HeLa, WiDr, T47D and Vero. Dhaka Univ. J. Pharm. Sci. 2013, 12, 87-90.

47. Kumar, D.S.S.; Cheung, H.Y.; Lau, C.S.; Chen, F.; Hyde, K.D. In vitro studies of endophytic fungi from Tripterygium wilfordii with anti-proliferative activity on human peripheral blood mononuclear cells. J. Ethnopharmacol. 2004, 94, 295-300. [CrossRef] [PubMed] 